\title{
Morphoanatomical injuries in Pistia stratiotes L. (Araceae) as a result of exposure to clomazone in water
}

\author{
VICTOR HUGO V. RIBEIRO, ITALO A.C. COUTINHO, BRENDA T.B. ALENCAR, \\ CASSIA M. CABRAL, JOSE B. DOS SANTOS, EVANDER A. FERREIRA \& \\ DAYANA M.T. FRANCINO
}

\begin{abstract}
Contamination of water sources due to herbicide is of great concern. Clomazone is a pesticide with a high contamination potential which could possibility lixiviate to water streams. Changes caused by residual herbicide include flora modifications which are generally detrimental for some species. The lack of morphological studies performed in aquatic plants exposed to herbicide-contaminated environments has encouraged the development of our research. For the first time, we present a study that aimed to evaluate leaf injuries visible to the naked eye as well as microscopical effects which may be caused by clomazone on Pistia stratiotes. Pistia stratiotes was subjected to five concentrations of clomazone. Our analysis showed leaf injuries, especially after 15 days of clomazone application. Hormesis was observed when the water lettuce was subjected to the lower concentrations. Total leaf area showed increase following by reduction while injured until reaching the highest concentration. Although the concentrations of clomazone tested in our study are not lethal to water lettuce, such herbicide have still caused morphoanatomical damages on leaves which advocates for the use of $P$. stratiotes as a bioindicator of the presence of herbicides such as clomazone in water.
\end{abstract}

Key words: aquatic macrophyte, clomazone, herbicide, hormesis, leaf anatomy, water lettuce.

\section{INTRODUCTION}

A pesticide is any substance or mixture of substances of chemical or biological ingredients intended for repelling, destroying or controlling any pest, or even regulating plant growth (FAO/ WHO 2016). Worldwide pesticide production increased at a rate of more than $10 \%$ per year. From 1950 to 2000, the amount of pesticides used worldwide jumped from 0.2 million tons to more than 5 million tons (Carvalho 2017). In 2014, the Brazilian market of pesticides had grown $190 \%$ if compared to $93 \%$ growth of the global market, setting Brazil as a leader in the worldwide ranking of pesticide usages since
2008 (Rigotto et al. 2014). According to Agência Nacional de Vigilância Sanitária (ANVISA 2013), in the 2010/2011 harvest, there was a consumption of 936,000 tons of pesticides in Brazil, which earned US\$ 8.5 billion to enterprises that control $75 \%$ of that market (Rigotto et al. 2014). The release of genetically modified seeds and its spreading in agricultural areas are related to the subsequent increases in pesticides consumption, being the use of herbicides responsible for $45 \%$ of consumed volume, followed by fungicide (14\%) and insecticide (12\%) (Rigotto et al. 2014).

With the intensification of production in areas where water basins are found, comes 
great concern, resulting from herbicide use (Grützmacher et al. 2008). The aquatic environment is the main drain of pesticides (Britto et al. 2012). Contamination of both surface and ground water by pesticides is reported all over the world (Turgut 2003, Zhou et al. 2006, Lari et al. 2014) and it is one of the greatest environmental concerns (Konstantinou et al. 2006). When pesticides reach freshwater ecosystems, they may interact with both biotic and abiotic components, although abiotic factors can lead to its degradation, the interaction with the biotic parts may lead to hostile effects on the freshwater community (Schäfer et al. 2011). Although, pesticide occurrences in agricultural catchments will rarely lead to acute extermination of the majority of species (Cedergreen \& Rasmussen 2017), one cannot deny that peak pesticide concentrations can affect the species communities on sub-lethal endpoints which ultimately may lead into altered community structure and function (Schäfer et al. 2011, Cedergreen \& Rasmussen 2017).

Regarding herbicide molecules with contaminant potential of water streams, clomazone \{2-[(2-chlorofphenyl)methyl]-4.4dimethyl-3-isoxazolidinone) $\}$ is known as a potential threat to aquatic ecosystem (Van Scoy \& Tjeerdema 2014). This herbicide has high water solubility ( $1.1 \mathrm{mg} \mathrm{L}^{-1}$ at $23^{\circ} \mathrm{C}$ ) (Van Scoy \& Tjeerdema 2014) and is categorized as a nonpersistent pesticide, which DT50 value is 22.6 days (PPDB 2019). However, clomazone persistence in the soil may be over 150 days (EPA 2007). When applied to the soil it may lixiviate and reach deep layers in the soil (Rodrigues \& Almeida 2011) as well as surface and underground water (Caldas et al. 2010, Santos et al. 2015). Santos et al. (2015) detected clomazone in all collecting seasons in over $60 \%$ of water samples (i.e. a total of 32 wells and 13 water springs sampled). Such herbicide was detected at depths up to
$160 \mathrm{~m}$, which brings concerns for the potential impacts of clomazone on drinking water systems. Degradation and mineralization of clomazone seems to be biologically dependent (Mervosh et al. 1995) with major microbial transformation reactions involving hydroxylation (Liu et al. 1996). Moreover, monitoring of the clomazone in water samples has revealed that clomazone persists in agricultural water for at least 130 days, being present in $90 \%$ of the river water samples analyzed (Zanella et al. 2002). Several studies have investigated and found the presence of clomazone in waters (Caldas et al. 2011).

Clomazone is an isoxazolidinone acting directly in the plant photosynthetic process, impairing the formation of photosynthetic pigments in the biosynthetic pathway of carotenoids (Ferhatoglu \& Barrett 2006, Van Scoy \& Tjeerdema 2014), which play an important role protecting the plant's photosynthetic apparatus against harmful effects of light intensity (Merzlyak et al. 1999, Schreiber et al. 2013). Effects in human erythrocytes and the possible formation of reactive oxygen species have also been demonstrated (Santi et al. 2011).

Considering the amounts of herbicides annually applied for weed management and the necessity to constantly monitor environmental contamination, it is important to evaluate the quality of water as residual herbicides may reach water streams. Biomonitoring using aquatic macrophytes comes with several advantages when compared to other methods for monitoring water quality (Pedralli 2003). Macrophytes can be used as bioindicators to provide a secure and reliable evaluation of the environmental quality. Macrophytes are good bioindicators of changes occurring in water bodies as a result of humaninduced interferences (Lukács et al. 2009), on account of its practical application and low cost, hence being an efficient alternative to chemical 
and physical water analyses (Pita-Barbosa et al. 2009).

Leaf injuries visible to the naked eye stand out as the most used method to evaluate plant species sensitivity to several stress factors. This evaluation frequently requires validation through microscopy analysis (Reig-Armiñana et al. 2004, Pita-Barbosa et al. 2009). In the past years, researchers have used plant anatomy as a tool to study the effects of pollutants in plants (Sant'Anna-Santos et al. 2006, Sant'AnnaSantos \& Azevedo 2007, Pedroso \& Alves 2008). Microscopic evaluations are essential for an early diagnosis of damage even before such damages are visible on the outer plant body by the naked eye, especially contributing to elucidate phytotoxicity mechanisms (Sant'AnnaSantos \& Azevedo 2007).

Because of the water solubility of clomazone, the potentialimpact of such a herbicide onsurface water, groundwater and aquatic organisms is of great concern. The lack of morphoanatomical studies performed in aquatic plants exposed to herbicide-contaminated environments has encouraged the development of our research. As far as we are concerned, there are no reports on the literature regarding the effect of clomazone on Pistia stratiotes L. (Araceae), popularly known as water lettuce. For the first time, we present a study that aimed to evaluate leaf injuries visible to the naked eye as well as the microscopical effects which may be caused by clomazone on water lettuce. Our hypothesis is that even small concentrations of clomazone (i.e. 0.037, 0.111, 0.333 and $1.0 \mathrm{mg} \mathrm{L}^{-1}$ ) may still be able to cause leaf injuries on macrophytes.

\section{MATERIALS AND METHODS}

Pistia stratiotes specimens were collected in a lake in the Municipality of Diamantina
(Fig. 1) (State of Minas Gerais, Brazil). There is no historic of contamination issues in this area. Plants collected were kept in $5 \mathrm{~L}$ plastic pots with tap water at pH 6.5. The new clones produced at the ends of stolons were collected when rosettes presented $15 \mathrm{~cm}$ in diameter, in order to make the experimental design more consistent. The clones were then transferred to plastic pots (two plants per pot) under hydroponic systems with nutrient solution as described by Castellane \& Araújo (1995). The $\mathrm{pH}$ of the solution was daily checked with a portable pH meter (model PHTEK) and corrected to 6.5 when necessary. Nutrient solution was not renewed during acclimatization. Plants were acclimatized for 15 days and then subjected to five treatments with the following clomazone concentrations diluted in water (Gamit $360 \mathrm{~g}$ a.i. $\mathrm{L}^{-1}$ ) (Gamit 360 CS: Batch 24-17: Manufactured, Dec 2019: Expiration, Dec 2019): 0.0; 0.037; 0.111; 0.333; and $1.0 \mathrm{mg} \mathrm{L}^{-1}$.

Automatic pipettes with a volumetric capacity of $1 \mathrm{~mL}$ were used for the application of clomazone in the plastic pots holding $5 \mathrm{~L}$ of water. Standard solutions of clomazone were prepared in stock solution in $10 \mathrm{mmol} \mathrm{L}{ }^{-1} \mathrm{CaCl}_{2}$ as diluents. Clomazone was applied $2 \mathrm{~h}$ after transferring the plants to pots. In this way, it was possible to obtain concentrations at 0.037, 0.111, 0.333 and $1.0 \mathrm{mg} \mathrm{L}^{-1}$ in the water within pots. After clomazone application, a composite sampling of the pots was performed to ensure that initial concentrations corresponded to each treatment proposed.

The experiment was carried out in a greenhouse at Universidade Federal dos Vales do Jequitinhonha e Mucuri - Diamantina (Minas Gerais, Brazil) from March to May 2015 under controlled temperature and humidity conditions set at $\pm 24 \stackrel{\circ}{ } \mathrm{C}$ and $78 \%$, respectively, through a system of continuous aeration. A completely 
randomized block design with four replicates per concentration was used.

Injuries were daily observed and documented by means of photos taken with a mobile phone (Samsung Galaxy A3) equipped with a 13 Mp digital camera of $4128 \times 3096$ pixel resolution.

At day 7 and 15 after the herbicide application, samples from the leaf middle area of fully expanded leaf areas that were apparently healthy (i.e. green areas) were collected and fixed in FAA50 (formaldehyde, acetic acid and 50\% ethanol; 1:1:18 by volume) (Johansen 1940), being later stored in 70\% ethanol. Two $\sim 0.5 \mathrm{~cm}^{2}$ fragments were taken from the samples of each replicate, dehydrated through a graded ethanol series from 70 to $95 \%$ and embedded in methyl methacrylate resin (Historesin ${ }^{\circledR}$, Leica Instruments, Heidelberg, Germany) according to the manufacturer. Cross sections at $5 \mu \mathrm{m}$ thickness were made in a manual rotary microtome Model 80 (American Optical scientific instruments) - USA using stainless steel blade. Sections were stained with toluidine blue at pH 4.4 (O'Brien \& McCully 1981), dried at room temperature and mounted in synthetic resin dissolved in toluene (Permount, Fisher Scientific, NJ, USA). At least three slides with 15 sections each were made for each replicate. Observation and photographic record were carried out in a Primo Star, Zeiss ${ }^{\circledR}$ light microscope equipped with a digital camera (AxioCam ERc5s). Three photos for each slide were taken.

The general morphological characterization of the leaf structure of the species studied was performed using leaves not subjected to clomazone application. For the micromorphometrical analyses, linear measurements of the following characters were accounted by using ANATI QUANTI software, version 2.0 for Windows ${ }^{\circledR}$ (Aguiar et al. 2007): thickness of leaf blade, palisade parenchyma, adaxial epidermis, and abaxial epidermis.

Moreover, 21 and 45 days after application, the level of injury was determined in percentage of visible injuries occupying the rosette area. Evaluation of fresh mass increment was performed weighing the whole plants at 0, 7, 14, 21 and 28 days after application of the herbicide in a precision scale (SHIMADZU, BL3200H). The means obtained were transformed into percentage and fresh mass increment was calculated in relation to the difference of the fresh mass taken in the first weighing (at day 0) which was set at $100 \%$.

At 45 days, all leaves were collected and digitalized in SAMSUNG printer (LASERJET SCX4200). Determination of total leaf area (TLA) and injured leaf area (ILA) were also obtained by using the program ANATI QUANTI, version 2.0 for Windows ${ }^{\circledR}$ (Aguiar et al. 2007).

After the last plant collection, samples of the nutrient solution and of the plant material were analyzed for detection and quantification of clomazone residues as described by (Queiroz et al. 2012). We made use of the based on liquid chromatography triple quadrupole tandem mass spectrometry (LC-MS/MS): HPLC Finnigan Surveyor Thermo Scientific TSQ Triple Quadrupole LC-MS Systems. The volume of injection was $10 \mu \mathrm{L}$ and the mobile phase was acetonitrile and $1 \%$ acetic acid in gradient mode. Recovery tests $(n=3)$ were performed using a fortification level of 0.5; 1.0 and $2.0 \mathrm{mg}$ $\mathrm{Kg}^{-1}$ adding a standard solution of $5.0 \mathrm{mg} \mathrm{mL}^{-1}$ in methanol (Queiroz et al. 2012). The results were subjected to variance analysis and interpreted using regression test at 5\% level of significance. 


\section{RESULTS}

Clomazone residues were not found in solutions at lower concentrations of clomazone (0.037; $0.111 \mathrm{mg} \mathrm{L}^{-1}$ ) and in samples of plant tissue. On the other hand, for concentrations at 0.333 and $1.0 \mathrm{mg} \mathrm{L}^{-1}$, it was found 0.019 and $0.048 \mathrm{mg} \mathrm{L}^{-1}$ of clomazone residues in the nutrient solution, respectively. However, clomazone residues were not found in plant material subjected to such concentrations of clomazone.

When exposed with clomazone, water lettuce showed bleaching of young leaves which then evolved to necrosis, except for the lowest concentration tested, 0,037 $\mathrm{mg} \mathrm{L}^{-1}$ (Fig. 2). Plants subjected to the lowest concentration of clomazone tested, $0.037 \mathrm{mg} \mathrm{L}^{-1}$, did not show any symptoms in the rosette (Fig. 2b). However, injuries occupying $25 \%$ of the rosette area were observed when subjected to concentrations at
$0.111 \mathrm{mg} \mathrm{L}^{-1}$ (Fig. 2C) while injuries occupying 50 to $75 \%$ of the rosette area were observed in plants exposed to 0.333 and $1.0 \mathrm{mg} \mathrm{L}^{-1}$, respectively (Fig. $2 d, e)$.

Total leaf area and injured leaf area analyses indicated lower mean value of total leaf area $\left(17 \mathrm{~cm}^{2}\right)$ for plants growing at $0.52 \mathrm{mg} \mathrm{L}^{-1}$ concentrations of clomazone and higher mean value of injured leaf $\left(10.21 \mathrm{~cm}^{2}\right)$ at $0.68 \mathrm{mg} \mathrm{L}^{-1}$ concentrations (Fig. 3). Water lettuce showed increase of fresh mass following the days of evaluation, being represented in the graph by straight lines. The highest values were observed for plants growing at $0.037 \mathrm{mg} \mathrm{L}^{-1}$ concentration which presented an equation with the highest slope coefficient (2.34) (Fig. 4).

Anatomically, the leaf blades of water lettuce are constituted by a single-layered epidermis with tabular to rounded cells and pluricellular-uniseriate trichomes on both leaf

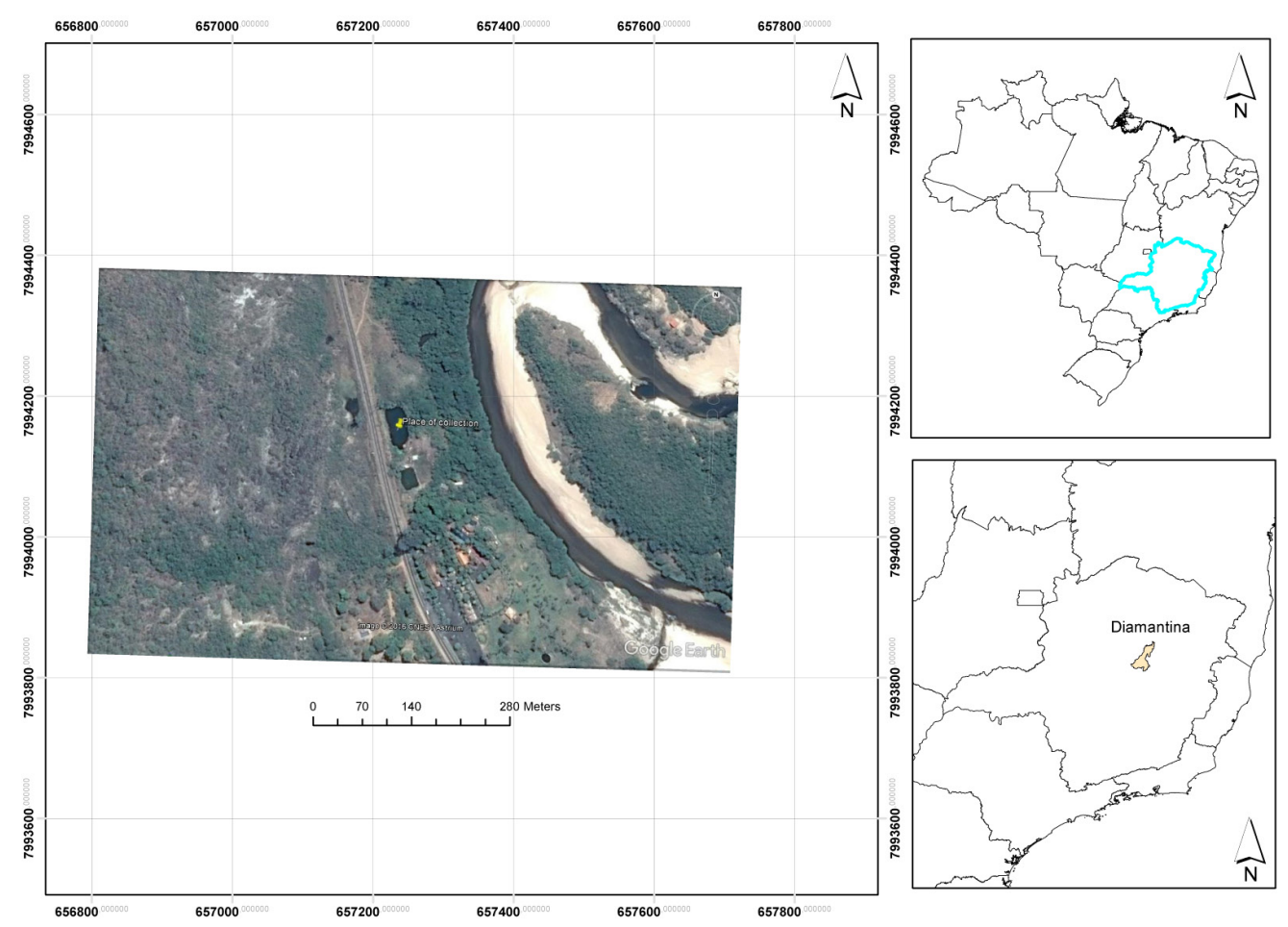

Figure 1. Area of collection of $P$. stratiotes at Diamantina, Minas Gerais State, Brazil. 
surfaces (Fig. 5a). Leaves are amphistomatic and mesophyll is dorsiventral (Fig. 5a), made up by a palisade parenchyma turned to adaxial side (Fig. 5a) and aerenchyma to the abaxial side, as the air-gaps are involved by braciform cells that interrupt the intercellular spaces. Idioblasts with calcium oxalate crystals (raphides and druses) are observed in the palisade parenchyma and aerenchyma (Fig. 5a). Collateral vascular bundles are placed in the
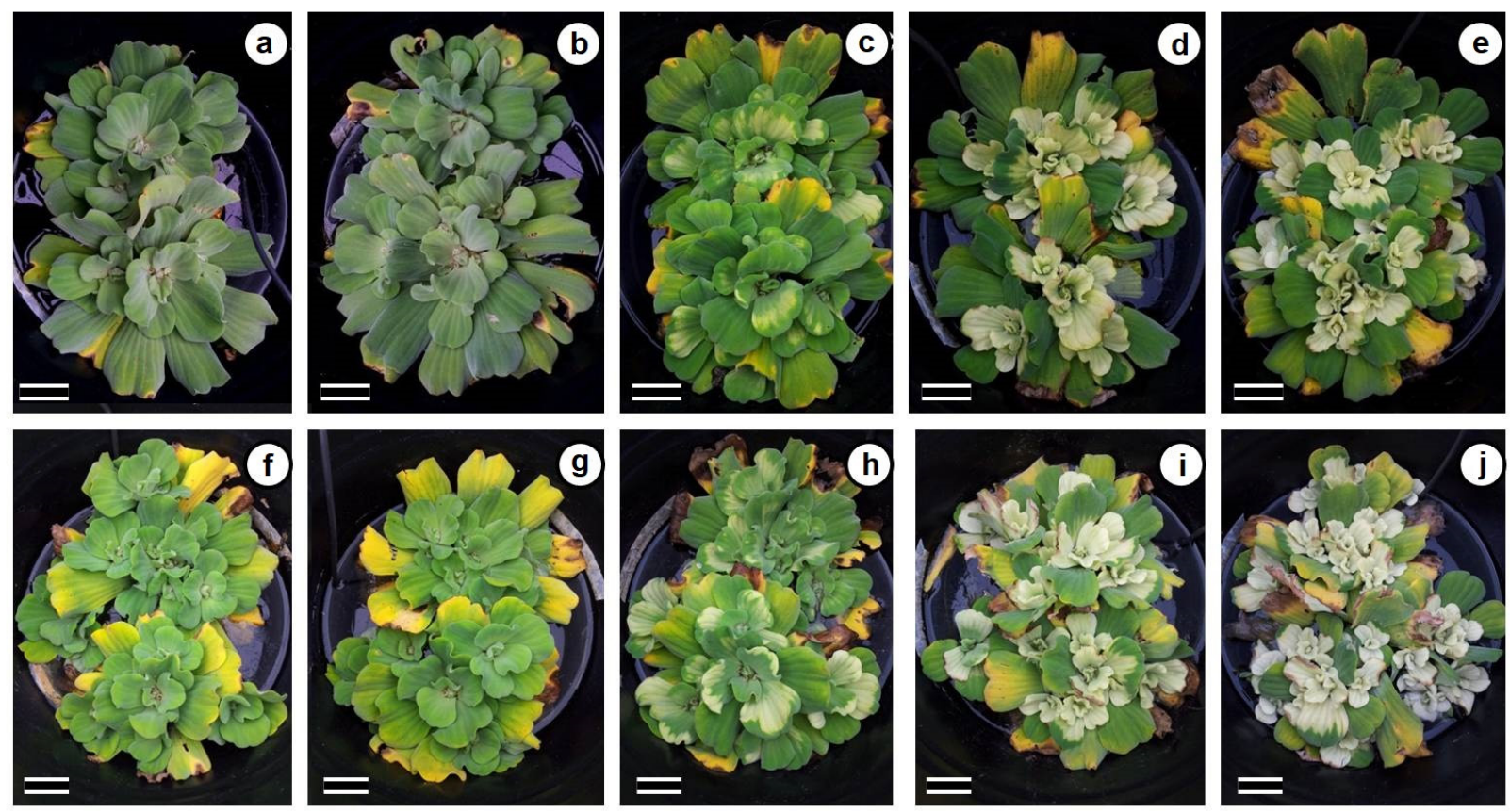

Figure 2. Pistia stratiotes injuries observed at 21 (a-e) and $45(\mathbf{f}-\mathbf{j})$ days after clomazone application. $\mathbf{a}$ and $\mathbf{f}$.

Control $0.0 \mathrm{mg} \mathrm{L}^{-1} ; \mathrm{b}$ and g. $0.037 \mathrm{mg} \mathrm{L}^{-1} ; c$ and h. $0.111 \mathrm{mg} \mathrm{L}^{-1} ; \mathrm{d}$ and i. 0.333 and $e$ and j $1.0 \mathrm{mg} \mathrm{L}^{-1}$. Scale bar $=5 \mathrm{~cm}$.

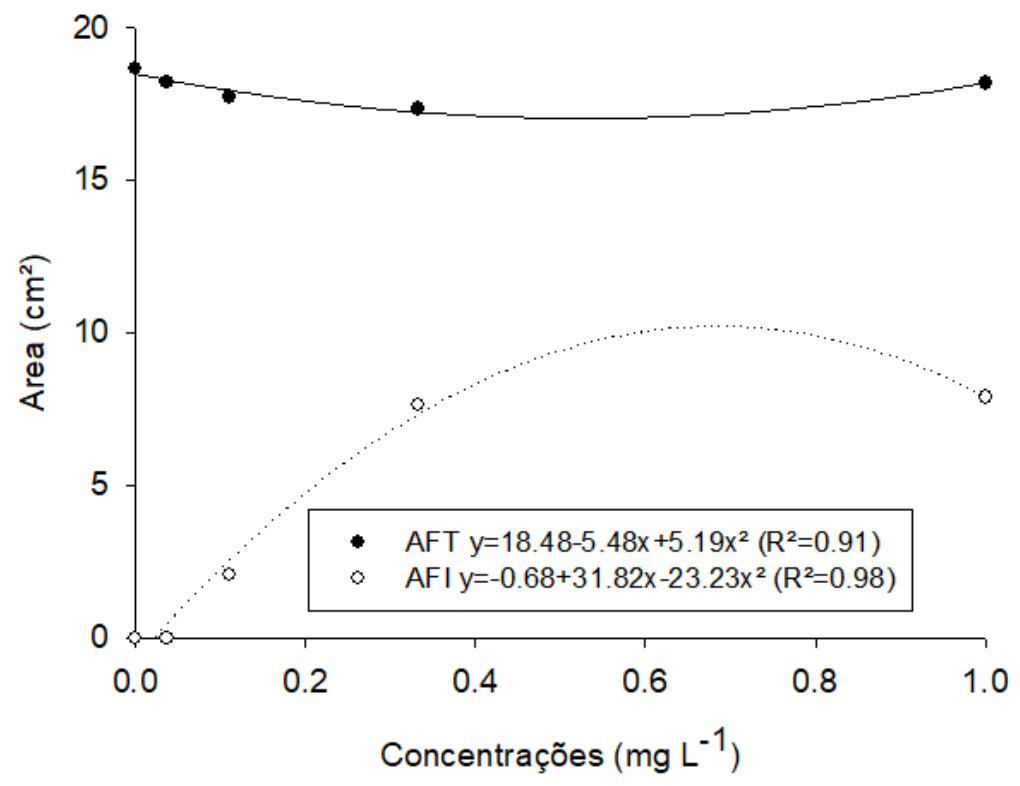

Figure 3. Total leaf area (TLA) and injured leaf area (ILA) of $P$. stratiotes at 45 days after clomazone application. 
median area of the mesophyll enclosed in a double bundle sheath (Fig. 5a).

Regarding the micromorphometrical analyses, the variable leaf blade thickness did not show statistical significance at 7 days, with mean value of $299.32 \mu \mathrm{m}$, as it may be observed in anatomical sections (Fig. 5b, c). However, at 15 days, it was observed an increase in the leaf blade thickness up to $0.49 \mathrm{mg} \mathrm{L}^{-1}$ of clomazone, following a reduction of thickness up to $1.0 \mathrm{mg} \mathrm{L}^{-1}$ (Fig. $5 \mathrm{~d}$, e and Fig. 6a). Palisade parenchyma thickness showed concave downward response curves at 7 and 15 days with the highest values (116.26 and $108.0 \mu \mathrm{m}$ ) observed at the concentrations of 0.64 and $0.57 \mathrm{mg} \mathrm{L}^{-1}$, respectively (Fig. 6b).

Changes on the adaxial epidermis thickness of leaves collected at 7 days were not statistically significant with mean of $19.78 \mu \mathrm{m}$ as observed in anatomical sections of plants subjected to 0.111 and $1.0 \mathrm{mg} \mathrm{L}^{-1}$ (Fig. 5b, c) which made it unsuitable to an adequate model. On the other hand, for leaves collected at 15 days, higher values for adaxial epidermis thickness $(21.87 \mu \mathrm{m})$ were accounted at the $0.54 \mathrm{mg} \mathrm{L}^{-1}$ concentration of clomazone (Fig. 6c), as observed in anatomical sections of plants subjected to 0.037 and $1.0 \mathrm{mg}$ $\mathrm{L}^{-1}$ (Fig. 5c, d).

Abaxial epidermis thickness of leaves collected at 7 days was not statistically significant with a mean value of $29.34 \mu \mathrm{m}$ (Fig. $5 b, c)$. However, leaves of plants subjected to at $0.67 \mathrm{mg} \mathrm{L}^{-1}$ concentration of clomazone and collected at 15 days showed lower mean values for thickness (20.5 $\mu \mathrm{m})$ (Fig. 6d), as observed in anatomical sections of plants subjected to 0.037 and $1.0 \mathrm{mg} \mathrm{L}^{-1}$ (Fig. 5c, d).

\section{DISCUSSION}

As clomazone residues were not found in plant tissues of individuals subjected to any of the solutions tested, one plausible explanation for this is that the residual clomazone which would be present in the plant tissues was

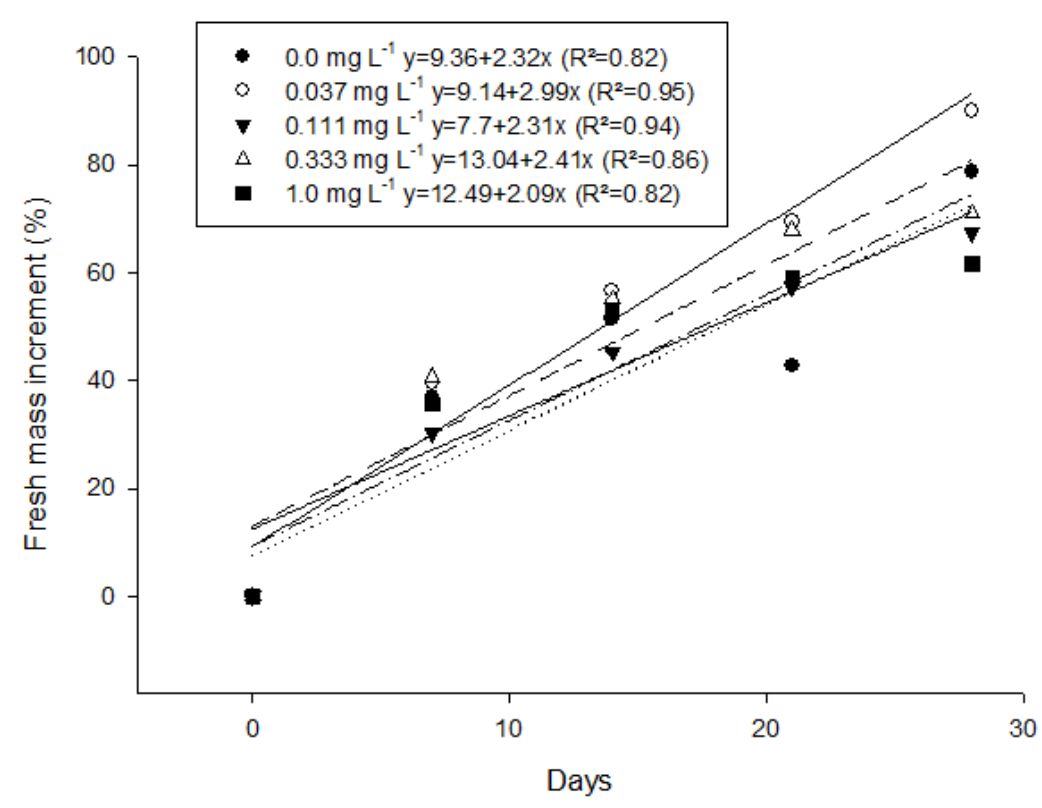

Figure 4. Fresh mass (\%) of $P$. stratiotes following clomazone application. Means of values of fresh mass refer to control (without herbicide): 0 day $=123.75 \mathrm{~g} ; 7^{\text {th }}$ day $=169.46 \mathrm{~g} ; 4^{\text {th }}$ day $=187.52 \mathrm{~g} ; 21^{\text {st }}$ day $=176.53 \mathrm{~g}$ and $28^{\text {th }}=$ $221.03 \mathrm{~g}$. 


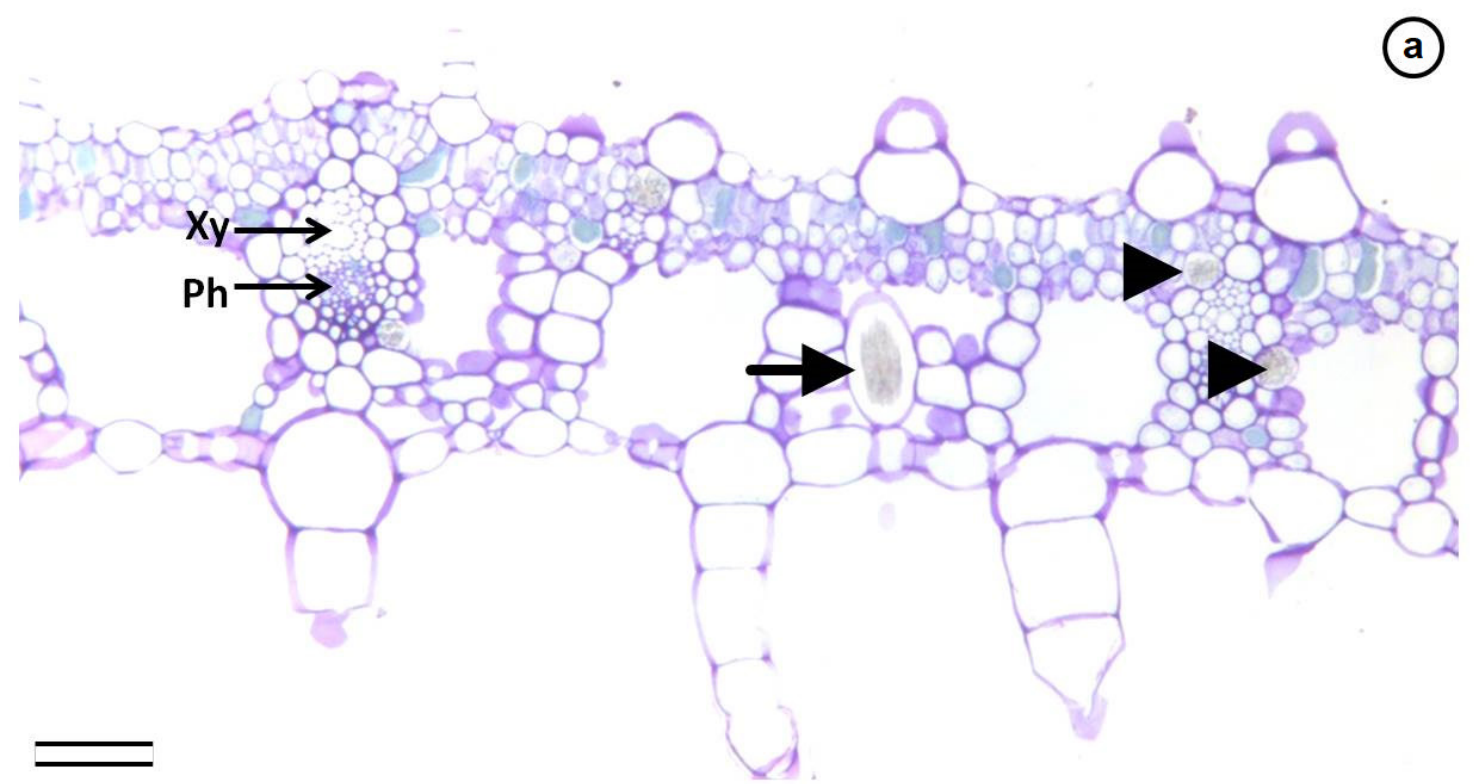

(b)
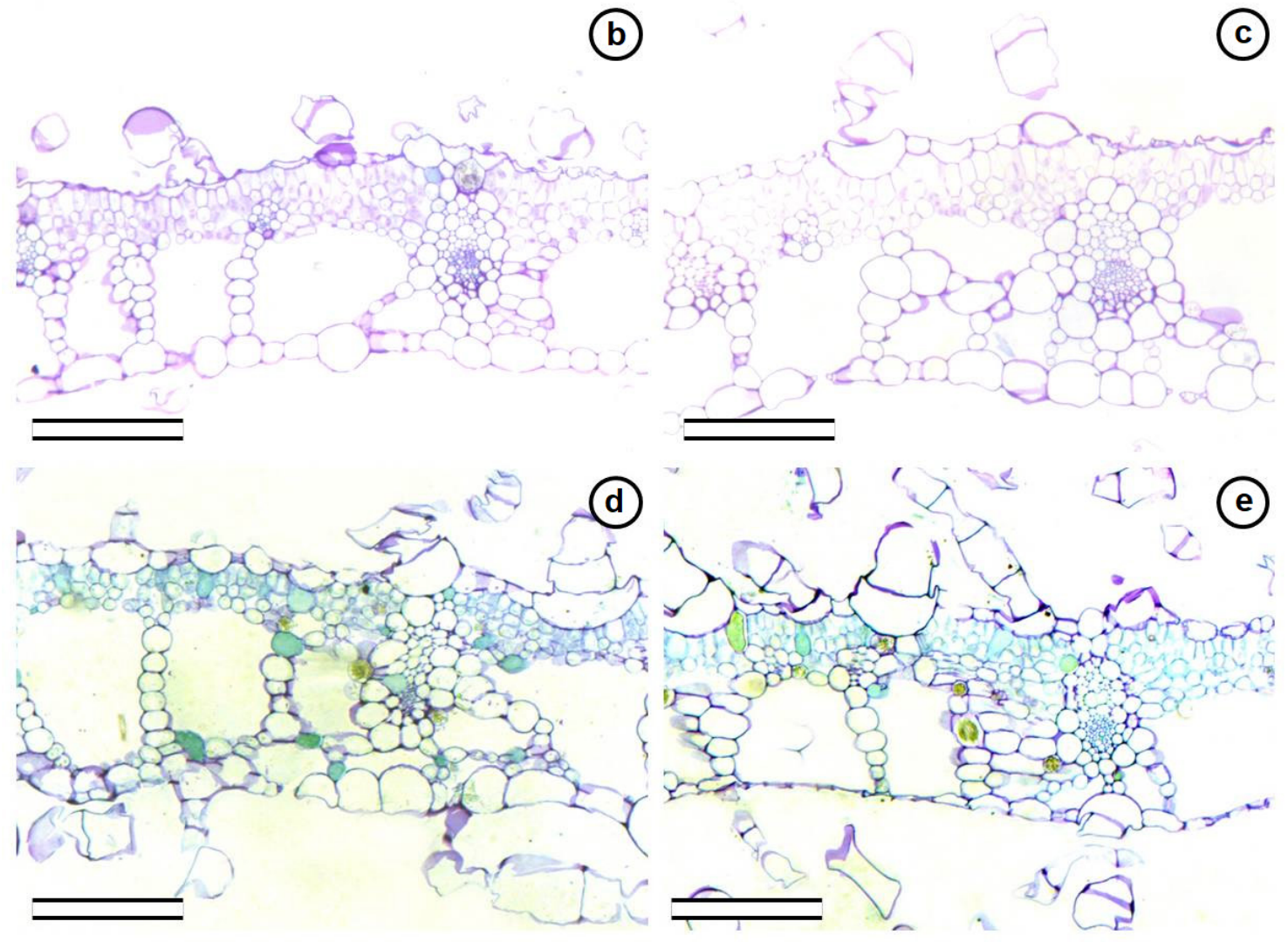

Figure 5. Cross sections of leaf blade of $P$. stratiotes subjected to clomazone application. $\mathbf{a}$. Control; $\mathbf{b}$ and $\mathbf{c}$. Plants subjected to 0.111 and $1.0 \mathrm{mg} \mathrm{L}^{-1}$ at 7 days after clomazone application. Note that the thickness of leaf blade does not change significantly regardless of the concentration of clomazone applied. $\mathbf{d}$ and e. Plants subjected to 0.037 and $1.0 \mathrm{mg} \mathrm{L}^{-1}$ at 15 days after clomazone application. Note that the abaxial epiderm is in $\mathbf{e}$ is much thinner than in $\mathbf{d}$ while the palisade parenchyma in $\mathrm{e}$ is thicker than in $\mathbf{d}$. arrowhead = druse; arrow = raphide; $\mathrm{Ph} v$ phoem; $\mathrm{Xy}=$ xylem. 

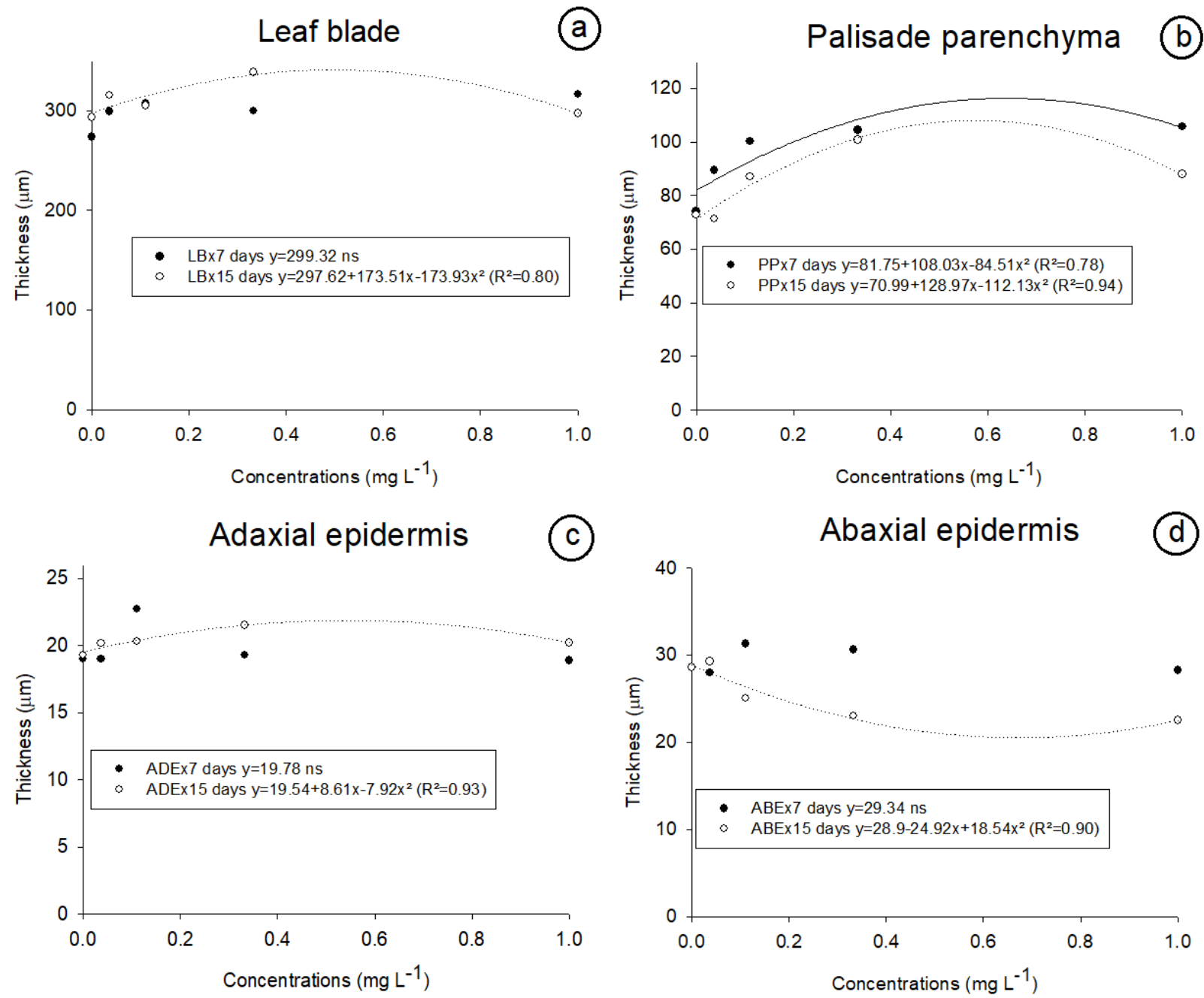

Figure 6. Thickness of leaf tissues of $P$. stratiotes obtained from cross sections of leaf blades collected at 7 and 15 days after clomazone application. a. Leaf blade thickness; b. Palisade parenchyma thickness; c. Adaxial epidermis thickness; d. Abaxial epidermis thickness.

actually below the limit of detection. There is also the possibility of forming metabolites derived from clomazone and such metabolites were not screened in our study. Liu et al. (1996) have proposed a microbial breakdown route for clomazone. Metabolites such as 5-hydroxyclomazone, hydroxymethylclomazone, 2-chlorobenzyl alcohol and 3'-hydroxyclomazone were identified as metabolites derived from the clomazone breakdown by common soil fungus and bacterium. Clomazone photodecomposition may also take place, with formation of four major photoproducts which were tentatively identified as 2-chlorobenzamide, $\mathrm{N}$-hydroxy-(2-benzyl)-2-methylpropan-amide, 2-[2-phenol]-4,4-dimethyl-3-isoxazolidinone and 2-[(4,6-dihydroxyl-2-chlorine phenol)]-4,4dimethyl-3-isoxazolidinone (Cao et al. 2013). Degradation of clomazone under UV light is faster (half-life of 51-59 min) when compared to sunlight (half-life of 87-136 d) (Cao et al. 2013). Metabolites such as hydroxyclomazone, hydroxymethylclomazone and 5-keto-clomazone 
were also reported to be found in plants (PPDB 2019).

Water lettuce showed bleaching of young leaves which then evolved to necrosis, except for the lowest tested concentration. Bleaching is a characteristic symptom of plants sensitive to this group of herbicide (i.e. isoxazolane) (Senseman 2007). Clomazone mode of action promotes lipid peroxidation in cells due blocking of carotenoid synthesis in emerging shoot, resulting in a characteristic bleaching of new leaf tissues (Yasuor et al. 2008). The macrophyte Azolla caroliniana Willd. also presented injuries when exposed to clomazone concentrations ranging from 0.6 to $0.8 \mathrm{mg} \mathrm{L}^{-1}$ (Silva et al. 2012). Therefore, the sensitivity of water lettuce when exposed to clomazone is evident as even low concentrations of this product results in plant intoxication.

Leaf area is of great importance for modelling growth and development of plants (Lima et al. 2012). Total leaf area and injured leaf area analyses indicated lower mean value of total leaf area for plants growing at $0.52 \mathrm{mg} \mathrm{L}^{-1}$ concentrations of clomazone while higher mean value was found at $0.68 \mathrm{mg} \mathrm{L}^{-1}$. Leaf surface expansion provides a better use of sunlight and therefore an increase in the photosynthetic capacity which makes it a good feature to evaluate plant growth (GonzálezSanpedro et al. 2008).

However, this study showed that water lettuce increases in injured leaf area because of clomazone action. The mechanism of action of this herbicide acts in the pathway of the carotenoid biosynthesis. The carotenoids are responsible for protecting leaves against excessive light intensity as light intercepted by leaves without such photo-protectors may cause photo-oxidation and chlorophyll eradication (Takahashi et al. 2009). Such a fact highlights the herbicide action which indirectly interferes on photosynthesis leading to bleaching.

Although water lettuce showed increases of fresh mass after being subjected to clomazone, such increase cannot be actually related to a good quality gain in fresh mass as bleaching clearly worsens as the concentration become higher and the days pass by. The possible evidence for the cause of the higher allocation of fresh mass under low concentration effect is the hormesis effect. Calabrese \& Blain (2009) argues that hormesis is a dose response phenomenon causing stimulatory effects at lower doses while at higher doses inhibitory. Such relation has quantitative features that are precise, as there are well stablished boundaries between stimulating and toxic effects.

Considering that the action mechanisms of clomazone acts in the elimination of the precursor of carotenoids, low herbicide concentrations (as applied in our study) may actually stimulate plants to produce new compounds without promoting excessive damage to the area that has already been synthesized. In such a way, the plant could become more tolerant to photodamages and consequently have chlorophyll better protected. The final effect would be a better allocation of resources, based on light use, supported by increases in fresh mass. Velini et al. (2008) reported growth stimulation on vegetative organs of soybean, eucalyptus, corn, pinus, coffee and citrus, when low doses of glyphosate simulating herbicide drift were applied.

The variable leaf blade thickness did not show statistical significance at 7 days. However, at 15 days after being subjected to clomazone, an increase in the leaf blade thickness was observed, following a reduction of thickness. Palisade parenchyma thickness showed concave downward response curves. Leaf blade thickness is generally determined by the 
expansion of photosynthetic tissue (Rôças et al. 1997), for example, the increase of the palisade parenchyma layers (Rôças et al. 1997, Cao 2000). As the photosynthetic tissues increases when exposed to clomazone concentrations up to $0.49 \mathrm{mg} \mathrm{L}^{-1}$ ), it seems that the areas in the leaf that are still apparently healthy (i.e. green when observed with the naked eye) try to compensate for other leaf areas that are not photosynthetic active (i.e. areas that are suffering with bleaching). Besides, light can be propagated through the central vacuole of the palisade cells and through air spaces between the cells, distributing light more uniformly to chloroplasts within the leaf (Vogelmann \& Martin 1993). However, in concentrations of clomazone around $1.0 \mathrm{mg} \mathrm{L}^{-1}$, the photosynthetic tissue decreases, supporting the idea that the plant is not able to compensate the issues caused by the bleaching. Palisade parenchyma thickness is also important to protect leaves against high luminous radiation (Tuffi Santos et al. 2008).

Palisade parenchyma thickness plays an important function to protect leaves against high luminous radiation (Tuffi Santos et al. 2008), as well as leaf blade thickness. Therefore, water lettuce probably increases the palisade parenchyma and leaf blade thickness as a mechanism of defense against the light intensity, since the plants are growing in solution treated with clomazone which destroy carotenoid biosynthesis and then reducing the ability of these pigments to dissipate the excess of energy from light in the plant shoot (Odero et al. 2015).

changes on the adaxial epidermis thickness of leaves collected at 7 days were not statistically significant in plants subjected to 0.111 and $1.0 \mathrm{mg} \mathrm{L}^{-1}$ which made it unsuitable to an adequate model. On the other hand, for leaves collected at 15 days, higher values for adaxial epidermis thickness were accounted at the $0.54 \mathrm{mg} \mathrm{L}^{-1}$ concentration of clomazone. As discussed by Cen \& Bornman (1993), an increase in the adaxial epidermis thickness determines the leaf precautionary effect towards water loss and mitigation of sun rays penetration in the leaf blade. Studies demonstrate that the main barrier to herbicide penetration in leaves is the occurrence of thicker adaxial epidermis and cuticle (Procópio et al. 2003). Adaxial epidermis plays important functions such as leaf surface protection against excessive light, control of gas exchanges and water vapor, as well as protection of the mesophyll (Dickson 2000, Evert 2006). Therefore, our results can be explained in the light of defense mechanisms as the studied species attempts to amend and overcome injurious effects caused by luminous intensity along with herbicide action. Our study indicates that water lettuce possibly has increased the adaxial epidermis thickness as a defense mechanism attempting to reduce the damage caused by the light with herbicide action. Thus, this thicker tissue assists to protect the whole mesophyll.

Although abaxial epidermis thickness of leaves collected at 7 days was not statistically significant, leaves of plants growing at 0.67 $\mathrm{mg} \mathrm{L}^{-1}$ concentration of clomazone which were collected at 15 days showed lower mean values for thickness. Due to its physical-chemical characteristics, clomazone is relatively volatile with highly vapor pressure $\left(19.2 \mathrm{mPa}\right.$ at $25{ }^{\circ} \mathrm{C}$ ) (Senseman 2007, Rodrigues \& Almeida 2011, Van Scoy \& Tjeerdema 2014, PPDB 2019). It is possible that the clomazone that would be lost by volatilization was actually kept under the abaxial side of the leaf surface for a while in a way that the abaxial side of leaf surface acted as a barrier to the escape of clomazone to the atmosphere. That may be the reason why a reduction on the thickness of the abaxial epidermis was observed. 
Even with absorption of the herbicide by target plants, residues of the clomazone may leach and reach groundwater yielding a potentially hazardous impact. The lowest concentration of clomazone tested was 0.037 $\mathrm{mg} \mathrm{\textrm {L } ^ { - 1 }}$ which would be equivalent to $26 \mathrm{~g} \mathrm{ha}^{-1}$. Considering that the label rate for clomazone application is $360 \mathrm{~g}$ a.i. ha-1 (up to $1260 \mathrm{~g}$ a.i. ha ${ }^{-1}$ ) (MAPA 2017), even $0.037 \mathrm{mg} \mathrm{L}^{-1}$ which is equivalent to $3 \%$ of the average recommended dose by the manufacturer would still injure plants.

Water lettuce was more sensitive when exposed to 0.333 and $1.0 \mathrm{mg} \mathrm{L} \mathrm{L}^{-1}$ clomazone concentrations, presenting higher degrees of intoxication. Anatomical studies showed that 15 days after plants exposure to the herbicide would be the adequate timing to perform micromorphometric evaluations as the evidences of tissue modifications are better observed at that time. Although our anatomical study was only based on leaves, the necessity to evaluate how roots are affected by herbicides is at demand as such organ may also be affected by the uptake of herbicides, as shown for Pinus radiata D.Don. (Marks \& Becker 1990).

\section{CONCLUSION}

Although the concentrations of clomazone tested in our study are not lethal to water lettuce, such herbicide have still caused morphoanatomical damages on leaves which advocates for the use of $P$. stratiotes as a bioindicator of the presence of herbicides such as clomazone in water. However, future studies evaluating the sensitivity of other organs, such as roots, to clomazone could indicate which organ is more suitable for biomonitoring of waters when using P. stratiotes. Studies subjecting P. stratiotes to other herbicides would confirm whether such species is affected by other herbicides or only clomazone. Although the acceptable daily intake of clomazone by livestock is $0.12 \mathrm{mg} \mathrm{Kg}^{-1}$ (PPDB 2019), our results show that a slight change in such a concentration (i.e. 0.111 in our study) may still affect other organisms that are more sensitive and that should be taken into account by environmental protection agencies.

\section{Acknowledgments}

We thank Conselho Nacional de Desenvolvimento Científico e Tecnológico (CNPq) and Fundação de Amparo à Pesquisa do Estado de Minas Gerais (FAPEMIG) for the financial support and Miss Daisy Burris B.Sc. in Biology (Imperial College UK) for her generous assistance on the language editing. This research did not receive any specific grant from funding agencies in the public, commercial, or not-for-profit sectors.

\section{REFERENCES}

AGUIAR TV, SANT'ANNA-SANTOS BF, AZEVEDO AA \& FERREIRA RS. 2007. ANATI QUANTI: software de análises quantitativas para estudos em anatomia vegetal. Planta Daninha 25: 649-659.

ANVISA - AGÊNCIA NACIONAL DE VIGILÂNCIA SANITÁRIA. 2013. PROGRAMA DE ANÁLISE DE RESÍDUOS DE AGROTÓXICOS EM ALIMENTOS. (PARA). http://portal.anvisa.gov.br/ documents/111215/446359/Programa+de+Análise+de+ Resíduos+de+Agrotóxicos+-+Relatório+2011+e+2012+\%2 81 ${ }^{\circ}+$ etapa\%29/d5e91ef0-4235-4872-b180-99610507d8d5. Accessado 20 Jul 2017.

BRITTO FB, VASCO AN, PEREIRA APS, MÉLLO JÚNIOR AV \& NOGUEIRA LC. 2012. Herbicidas no alto rio Poxim, Sergipe e os riscos de contaminação dos recursos hídricos. Rev Ciência Agronômica 43: 390-398.

CALABRESE EJ \& BLAIN RB. 2009. Hormesis and plant biology. Environ Pollut 157: 42-48.

CALDAS SS, DEMOLINER A, COSTA FP, D'OCA MGM \& PRIMEL EG. 2010. Pesticide residue determination in groundwater using solid-phase extraction and high-performance liquid chromatography with diode array detector and liquid chromatography-tandem mass spectrometry. J Braz Chem Soc 21: 642-650.

CALDAS SS, ZANELLA R \& PRIMEL EG. 2011. Risk estimate of water contamination and occurrence of pesticide in the South of Brazil. In: Kortekamp A (Ed), Herbicides and Environment. Intechopen, p. 471-492. 
CAO J, DIAO XP \& HU JY. 2013. Hydrolysis and photolysis of herbicide clomazone in aqueous solutions and natural water under abiotic conditions. J Integ Agr 12: 2074-2082.

CAO KF. 2000. Leaf anatomy and chlorophyll content of 12 woody species in contrasting light conditions in a Bornean heath forest. Can J Bot 78: 1245-1253.

CARVALHO FP. 2017. Pesticides, environment, and food safety. Food Energy Secur 6: 48-60.

CASTELLANE PD \& ARAÚJO JAC. 1995. Cultivo sem solo: hidroponia. FUNEP, Jaboticabal, Sao Paulo, Brasil.

CEDERGREEN N \& RASMUSSEN JJ. 2017. Low dose effects of pesticides in the aquatic environment. In: Duke SO, Kudsk P and Solomon K (Eds), Pesticide Dose: Effects on the Environment and Target and Non-Target Organisms. American Chemical Society, Washington, DC, p. 167-187.

CEN YP \& BORNMAN JF. 1993. The effect of exposure to enhanced UV-B radiation on the penetration of monochromatic and polychromatic UV-B radiation in leaves of Brassica napus. Physiol Plant 87: 249-255.

DICKSON WC. 2000. Integrative plant anatomy. Academic Press, USA.

EVERT RF. 2006. Esau's Plant Anatomy: Meristems, Cells, and Tissues of the Plant Body: Their Structure, Function, and Development. J Wiley \& Sons, Inc., Hoboken, New Jersey, USA.

EPA - ENVIRONMENTAL PROTECTION AGENCY. 2007. Docket Number: EPA-HQ-OPP-2006-0113.

FAO/WHO. 2016. Manual on development and use of FAO and WHO specifications for pesticides. http://www.fao. org/3/a-i5713e.pdf. Accessed 20 Jul 2017.

FERHATOGLU Y \& BARRETT M. 2006. Studies of clomazone mode of action. Pestic Biochem Physiol 85: 7-14.

GONZÁLEZ-SANPEDRO MC, LE TOAN T, MORENO J, KERGOAT L \& RUBIO E. 2008. Seasonal variations of leaf area index of agricultural fields retrieved from Landsat data. Remote Sens Environ 112: 810-824.

GRÜTZMACHER DD, GRÜTZMACHER AD, AGOSTINETTO D, LOECK AE, ROMAN R, PEIXOTO SC \& ZANELLA R. 2008. Monitoramento de agrotóxicos em dois mananciais hídricos no sul do Brasil. Rev Bras Eng Agrícola e Ambient 12: 632-637.

JOHANSEN DA. 1940. Plant microtechnique. McGraw-Hill Book, New York.

KONSTANTINOU IK, HELA DG \& ALBANIS TA. 2006. The status of pesticide pollution in surface waters (rivers and lakes) of Greece. Part I. Review on occurrence and levels. Environ Pollut 141: 555-570.
LARI SZ, KHAN NA, GANDHI KN, MESHRAM TS \& THACKER NP. 2014. Comparison of pesticide residues in surface water and ground water of agriculture intensive areas. J Environ Heal Sci Eng 12: 11.

LIMA RT, SOUZA PJOP, RODRIGUES JC \& LIMA MJA. 2012. ModeloS para estimativa da área foliar da mangueira utilizando medidas lineares. Rev Bras Frutic 34: 974-980.

LIU SY, SHOCKEN M \& ROSAZZA JPN. 1996. Microbial transformations of clomazone. J Agric Food Chem 44: 313-319.

LUKÁCS BA, DÉVAI G \& TÓTHMÉRÉSZ B. 2009. Aquatic macrophytes as bioindicators of water chemistry in nutrient rich backwaters along the Upper-Tisza river (in Hungary). Phytocoenologia 39: 287-293.

MAPA - MINISTÉRIO DE AGRICULTURA, PECUÁRIA E ABASTECIMENTO. 2017. AgROFIT (Sistema de Agrotóxicos fitossanitários (Consulta Aberta).

MARKS G \& BECKER S. 1990. Influence of propazine and chlorthal dimethyl on mycorrhizal development in Pinus radiata seedlings. Aust J Bot 38: 341.

MERVOSH TL, SIMS GK \& STOLLER WE. 1995. Clomazone fate in soil as affected by microbial activity, temperature, and soil moisture. J Agric Food Chem 43: 537-543.

MERZLYAK MN, GITELSON AA, CHIVKUNOVA OB \& RAKITIN VY. 1999. Non-destructive optical detection of pigment changes during leaf senescence and fruit ripening. Physiol Plant 106: 135-141.

O'BRIEN TP \& MCCULLY ME. 1981. The study of plant structure principles and selected methods. Termarcarphi Ptey. Ltd., Melbourne, Australia, p. 357.

ODERO DC, FERNANDEZ JV, SANDHU HS \& SINGH MP. 2015. Response of Eeergycane to preemergence and postemergence herbicides. Weed Technol 29: 810-820.

PEDRALli G. 2003. Macrófitas aquáticas como bioindicadoras da qualidade da água: alternativas para uso múltiplos de reservatórios. In: Thomaz SM and Bini LM (Eds), Ecologia e manejo de macrófitas aquáticas. Eduem, Maringá, Paraná, Brasil, p. 171-188.

PEDROSO ANV \& ALVES ES. 2008. Anatomia foliar comparativa das cultivares de Nicotiana tabacum L. (Solanaceae) sensível e tolerante ao ozônio. Acta Bot Brasilica 22: 21-28.

PITA-BARBOSA A, SANT'ANNA-SANTOS BF, SILVA KLF, AZEVEDO AA \& ROCHA DI. 2009. Efeitos fitotóxicos do fluoreto na morfoanatomia foliar de Brachiaria brizantha (Hochst. ex A. Rich.) Stapf e Brachiaria decumbens Stapf (Poaceae). Acta Bot Brasilica 23: 1027-1033. 
PPDB - PESTICIDE PROPERTIES DATABASE. 2019. https://sitem. herts.ac.uk/aeru/ppdb/en/Reports/168.htm. Accessed 10 Feb 2019.

PROCÓPIO SO, SILVA EAM, SILVA AA \& FERREIRA EA. 2003. Anatomia foliar de plantas daninhas do Brasil. Editora UFV, Viçosa, Minas Gerais, Brasil, p. 10-116.

QUEIROZ SCN, FERRACINI VL \& ROSA MA. 2012. Validação de método multirresíduo para determinação de pesticidas em alimentos empregando QUEChERS e UPLC-MS/MS. Quim Nova 35:185-192.

REIG-ARMIÑANA J, CALATAYUD V, CERVERÓ J, GARCÍA-BREIJO F, IBARS A \& SANZ M. 2004. Effects of ozone on the foliar histology of the mastic plant (Pistacia lentiscus L.). Environ Pollut 132: 321-331.

RIGOTTO RM, VASCONCELOS DP \& ROCHA MM. 2014. Pesticide use in Brazil and problems for public health. Cad Saude Publica 30: 1360-1362.

RÔÇAS G, BARROS CF \& SCARANO FR. 1997. Leaf anatomy plasticity of Alchornea triplinervia (Euphorbiaceae) under distinct light regimes in a Brazilian montane Atlantic rain forest. Trees 11: 469-473.

RODRIGUES BN \& ALMEIDA FS. 2011. Guia de herbicidas, 6a ed, Londrina, Paraná, Brasil.

SANT'ANNA-SANTOS B, SILVA LC, AZEVEDO AA, ARAÚJO JM, FIGUEIREDO ALVES E, SILVA EAM \& AGUIAR R. 2006. Effects of simulated acid rain on the foliar micromorphology and anatomy of tree tropical species. Environ Exp Bot 58: 158-168.

SANT'ANNA-SANTOS BF \& AZEVEDO AA. 2007. Aspectos morfoanatômicos da fitotoxidez do flúor em duas espécies arbóreas tropicais. Rev Bras Biociências 5: 48-50.

SANTI A, MENEZES C, DUARTE M, LEITEMPERGER J, LÓPES T \& LORO V. 2011. Oxidative stress biomarkers and acetylcholinesterase activity in human erythrocytes exposed to clomazone (in vitro). Interdiscip Toxicol 4(3): 149-153.

SANTOS EA, CORREIA NM, SILVA JRM, VELINI ED, PASSOS ABRJ \& DURIGAN JC. 2015. Herbicide detection in groundwater in Córrego Rico-SP watershed. Planta Daninha 33: 147-155.

SCHÄFER RB, VAN DEN BRINK PJ \& LIESS M. 2011. Impacts of pesticides on freshwater ecosystems. Ecol Impacts Toxic Chem 111-137.

SCHREIBER F, AVILA LA DE, SCHERNER A, MOURA DDS \& HELGUEIRA DB. 2013. Plantas indicadoras de clomazone na fase vapor. Ciênc Rural 43: 1817-1823.
SENSEMAN SA. 2007. Herbicide handbook, $9^{\text {th }}$ ed. Weed Science Society of America, Lawrence, USA, p. 458.

SILVA AF, CRUZ CN, NETO A \& PITELLI RA. 2012. Ecotoxicidade de herbicidas para a macrófita aquática (Azolla caroliniana). Planta Daninha 30: 541-546.

TAKAHASHI EN, ALVES PLCA, SALGADO TP, FARIAS MA, SILVA $A C \&$ BIAGGIONI BT. 2009. Consequências da deriva de clomazone e sulfentrazone em clones de E. grandis x E. urophylla. Rev Árvore 33: 675-683.

TUFFI SANTOS LD, SANT'ANNA-SANTOS BF, MEIRA RMSA, TIBURCIO RAS, FERREIRA FA, MELO CAD \& SILVA EFS. 2008. Danos visuais e anatômicos causados pelo glyphosate em folhas de Eucalyptus grandis. Planta Daninha 26: 9-16.

TURGUT C. 2003. The contamination with organochlorine pesticides and heavy metals in surface water in Küçük Menderes River in Turkey, 2000-2002. Environ Int 29: 29-32.

VAN SCOY AR \& TJEERDEMA RS. 2014. Environmental Fate and Toxicology of Clomazone. In: de Voogt P (Ed), Reviews of Environmental Contamination and Toxicology. Springer International Publishing, p. 35-49.

VELINI ED, ALVES E, GODOY MC, MESCHEDE DK, SOUZA RT \& DUKE SO. 2008. Glyphosate applied at low doses can stimulate plant growth. Pest Manag Sci 64: 489-496.

VOGELMANN TC \& MARTIN G. 1993. The functional significance of palisade tissue: penetration of directional versus diffuse light. Plant, Cell Environ 16: 65-72.

YASUOR H, TENBROOK PL, TJEERDEMA RS \& FISCHER AJ. 2008. Responses to clomazone and 5-ketoclomazone by Echinochloa phyllopogon resistant to multiple herbicides in Californian rice fields. Pest Manag Sci 64: 1031-1039.

ZANELLA R, PRIMEL EG, MACHADO SLO, GONÇALVES FF \& MARCHEZAN E. 2002. Monitoring of the herbicide clomazone in environmental water samples by solid-phase extraction and high-performance liquid chromatography with ultraviolet detection. Chromatographia 55: 573-577.

ZHOU R, ZHU L, YANG K \& CHEN Y. 2006. Distribution of organochlorine pesticides in surface water and sediments from Qiantang River, East China. J Hazard Mater 137: 68-75. 


\section{How to cite}

RIBEIRO VHV, COUTINHO IAC, ALENCAR BTB, CABRAL CM, SANTOS JB, FERREIRA EA \& FRANCINO DMT. 2020. Morphoanatomical injuries in Pistia stratiotes L. (Araceae) as a result of exposure to clomazone in water. An Acad Bras Cienc 92: e20180519. DOI 10.1590/0001-3765202020180519.

Manuscript received on May 30, 2018; accepted for publication on March 7, 2019

VICTOR HUGO VIDAL RIBEIRO'

https://orcid.org/0000-0001-5532-0691

ÍTALO ANTÔNIO COTTA COUTINHO ${ }^{2}$

https://orcid.org/0000-0002-3571-0243

BRENDA THAIS BARBALHO ALENCAR ${ }^{1}$

https://orcid.org/0000-0002-9053-8802

\section{CÁSSIA MICHELLE CABRAL ${ }^{3}$}

https://orcid.org/0000-0002-4730-4509

\section{JOSÉ BARBOSA DOS SANTOS}

https://orcid.org/0000-0002-5746-7248

\section{EVANDER ALVES FERREIRA 4}

https://orcid.org/0000-0003-4701-6862

\section{DAYANA MARIA TEODORO FRANCINO ${ }^{3}$}

https://orcid.org/0000-0002-9160-1893

${ }^{1}$ Universidade Federal dos Vales do Jequitinhonha e Mucuri, Campus JK, Departamento de Agronomia, Laboratório de Plantas Daninhas, Rd. MGT 367, Km 583, № 5000, Alto da Jacuba, 39100-000 Diamantina, MG, Brazil

${ }^{2}$ Universidade Federal do Ceará, Campus do Pici, Departamento de Ciências Biológicas, Centro de Ciências, Laboratório de Anatomia Vegetal, Av. Mister Hull, s/n, 60440-900 Fortaleza, CE, Brazil

${ }^{3}$ Universidade Federal dos Vales do Jequitinhonha e Mucuri, Campus JK, Departamento de Ciências Biológicas, Laboratório de Anatomia Vegetal, Rd. MGT 367, Km 583, № 5000, Alto da Jacuba, 39100-000 Diamantina, MG, Brazil

${ }^{4}$ Universidade Federal de Minas Gerais/UFMG, Instituto de Ciências Agrárias/ICA, Campus Regional de Montes Claros, Avenida Universitária, 1.000, Bairro Universitário, 39404-547 Montes Claros, MG, Brazil

\section{Author contributions}

Brenda and Cássia gave technical support to set up and conduct the study. Ítalo contributed with his expertise in plant anatomy and writing the manuscript. Evander gave support in the statistical analysis and with his expertise in weed science. Dayana and Jose Barbosa were the supervisors of this research. Victor was in charge of conducting the experiment and writing the manuscript.

\section{(cc) BY}

Correspondence to: Victor Hugo Vidal Ribeiro

E-mail:victorhvribeiro@yahoo.com.br 